\title{
Inhibitory Effects of Red Wine Extracts on Endothelial- Dependent Adhesive Interactions with Monocytes Induced by Oxysterols
}

\author{
YUJI NAITO, MAKOTO SHIMOZAWA, HIROKI MANABE, MASAAKI KURODA, \\ NAOYA TOMATSURI, KAZUHIKO UCHIYAMA, TOMOHISA TAKAGI, NORIMASA \\ YOSHIDA and TOSHIKAZU YOSHIKAWA
}

First Department of Medicine, Kyoto Prefectural University of Medicine, Kyoto 602-8566, Japan

\begin{abstract}
Red wine polyphenolic compounds have been demonstrated to possess antioxidant properties, and several studies have suggested that they might constitute a relevant dietary factor in the protection from coronary heart disease. The aim of the present study is to examine whether red wine extracts (RWE) can ameliorate oxysterol-induced endothelial response, and whether inhibition of adhesion molecule expression is involved in monocyte adhesion to endothelial cells. Surface expression and mRNA levels of adhesion molecules (intercellular adhesion molecule 1 and vascular cell adhesion molecule 1) were determined by ELISA and RTPCR performed on human aortic endothelial cells (HAEC) monolayers stimulated with 7 $\beta$-hydroxycholesterol or 25-hydroxycholesterol. Incubation of HAEC with oxysterols $(10 \mu \mathrm{M})$ increased expression of adhesion molecules in a time-dependent manner. Pretreatment of HAEC with RWE at final concentrations of 1, 10, and $100 \mathrm{ng} / \mathrm{ml}$ significantly inhibited the increase of surface protein expression and mRNA levels. Adherence of monocytes to oxysterol-stimulated HAEC was increased compared to that of unstimulated cells. Treatment of HAEC with RWE significantly inhibited adherence of monocytes. These results suggest that RWE works as an anti-atherogenic agent through the inhibition of endothelial-dependent adhesive interactions with monocytes induced by oxysterols.
\end{abstract}

Key words: Adhesion molecule, monocyte-endothelial cell interaction, oxysterol, red wine extract.

Abbreviations: Chol: cholesterol; EIA: enzyme immunoassay; HAEC: human aortic endothelial cells; ICAM1: intracellular cell adhesion molecule-1; IL-1 $\beta$ : interleukin-1 $\beta$; M-CSF: macrophage-colony stimulating factor; oxLDL: oxidized low density lipoprotein; RWE: red wine extract; TNF- $\alpha$ : tumor necrosis factor- $\alpha$; VCAM-1: vascular cell adhesion molecule-1; VLA: very late antigen.

\section{INTRODUCTION}

The adherence of monocytes to vascular endothelial cells and their migration into the extravascular space are essential to the early process of atherogenesis. Monocytes are initially attracted to lesion-prone sites by cell-adhesion molecules expressed on activated endothelial cells. The initial adhesion involves selectins, which mediate a rolling interaction, that is followed by firmer attachment by means of integrins. Adherent monocytes migrate into the subendothelial space under the influence of chemoattractant molecules. Vascular cell adhesion molecule1 (VCAM-1) or intracellular cell adhesion molecule-1 (ICAM-1) may be candidates for the initial recruitment of macrophages, given their up-regulation in cultured endothelial cells in the presence of oxidized low density lipoprotein (oxLDL) (1). The significant role of adhesion molecules or macrophages in the process of atherosclerosis was recently confirmed by molecular biological techniques, in which knockout of ICAM-1 gene (2) or administration with monoclonal

Corresponding author: Yuji Naito, First Department of Medicine, Kyoto Prefectural University of Medicine, KawaramchiHirokoji, Kmaigyo-ku, Kyoto 602-8566, Japan. Phone: +81-75-251-5505. Fax: +81-75-252-3721. E-mail: ynaito@koto.kpu-m.ac.jp 
antibody against the receptor of macrophage-colony stimulating factor (MCSF) (3) significantly inhibited the progression of atherosclerosis in apolipoprotein E-deficient mice, which develop spontaneous lesions in the arterial vasculature with advanced lesions morphologically similar to those seen in humans, when fed a regular chow, high-fat, or high-cholesterol diet. These results indicate that inflammatory response, including the expression of adhesion molecules and the production of cytokines, plays a crucial role in the initial development of atherosclerosis.

A significantly reduced incidence of coronary heart disease despite a high-fat diet, little exercise, and wide-spread cigarette smoking in certain areas of France, has led to the concept of "French paradox" (4). This phenomenon was attributed to a higher intake of alcohol and, in particular, of red wine in France. Although several observations support a protective effect of red wine, there is no clear-cut evidence showing whether red wine is more beneficial than other forms of alcohol. Recently, it has been demonstrated that red wine polyphenols have various antiatherogenic effects (5), such as antioxidation of LDL-cholesterol (6, $7)$, inhibition of adhesion molecule expression in cytokine-stimulated vascular endothelial cells (8), inhibition of platelet aggregation (9), induction of nitric oxide release, and vasorelaxation (10).

Oxidation of LDL, produced by a variety of chemical and biochemical processes, is believed to be the major basis of atherogenicity of LDL (1). OxLDL contains several lipid-derived bioactive molecules such as oxysterols, phospholipids, and fatty acid peroxides. Among these, the major oxysterols have been identified as $7 \beta$ hydroxycholesterol and 7-ketocholesterol. The objectives of the present study were to examine whether model compounds for oxysterol can increase the expression of ICAM-1 and VCAM-1 on human aortic endothelial cells, and to determine in vitro effects of red wine extracts on the expression of these adhesion molecules and on monocyte adherence to endothelial cells induced by oxysterols.
METHODS

\section{Reagents}

Monoclonal antibodies for ICAM-1 and VCAM-1 were purchased from Becton Dickson (San Jose, CA). Red wine extract (RWE) was donated by Sunstar Co. Ltd. (Osaka, Japan), and contains a mixture shown in Table I.

\section{TABLE I}

Polyphenols Content of Red Wine Extract

- Total polyphenols: 5\%

- Catechins:

- Epigallocatechin:

- Epicatechingallate:

- Epigallocatechingallate:

- Gallocatechin:

- Quercetin:

- Resveratrol

- cis-resveratrol:

$<5 \mathrm{mg} / 100 \mathrm{~g}$

$<5 \mathrm{mg} / 100 \mathrm{~g}$

$<5 \mathrm{mg} / 100 \mathrm{~g}$

$5.5 \mathrm{mg} / 100 \mathrm{~g}$

$15 \mathrm{mg} / 100 \mathrm{~g}$

- trans-resveratrol:

$75 \mu \mathrm{M}$

$52 \mu \mathrm{M}$

- Anthocyanins

- Cyanidine-chloride:

$41 \mathrm{mg} / 100 \mathrm{~g}$

- Delphinidine-chloride:

$6.2 \mathrm{mg} / 100 \mathrm{~g}$

- Peonidine-chloride:

$0.6 \mathrm{mg} / 100 \mathrm{~g}$

\section{Endothelial cells}

Human aortic endothelial cells (HAEC) were obtained from Clonetics (San Diego, CA) and were cultured with endothelial cell growth medium (Clonetics) at $37^{\circ} \mathrm{C}$ in a humidified $95 \%$ air-5 \% $\mathrm{CO}_{2}$ atmosphere. After detaching confluent HAEC from the flasks with $0.025 \%$ trypsin, the cells were plated in 48- or 96-well tissue culture plates (Nunc). Cells were used in the experiments described below after three to four passages. Human monocytic U937 cells were purchased from the American Type Culture Collection (Rockville, MD) and grown in RPMI 1640 medium (Sigma Chemical Co., St Louis, MO) containing 10 $\%$ fetal calf serum, $100 \mu \mathrm{g} / \mathrm{ml}$ streptomycin, $100 \mathrm{IU} / \mathrm{ml}$ penicillin, $250 \mathrm{ng} / \mathrm{ml}$ fungizone at $37^{\circ} \mathrm{C}$ in a humidified $95 \%$ air-5 \% $\mathrm{CO}_{2}$ atmosphere. 


\section{Enzyme immunoassay}

Enzyme immunoassay (EIA) was used to assess the adhesion molecule expression on the human aortic endothelial cells (HAEC) monolayer. Confluent HAEC monolayers were pretreated with and without RWE for 10 $\mathrm{h}$, and then HAEC were stimulated with TNF$\alpha$, IL-1 $\beta, 7 \beta$-hydroxycholesterol, or 25hydroxycholesterol. After stimulation, HAEC were fixed, washed with PBS, and incubated in $2 \%$ bovine serum albumin. After removing bovine albumin, monoclonal antibodies directed against ICAM-1 or VCAM-1 were added and incubated at $37^{\circ} \mathrm{C}$ for $60 \mathrm{~min}$.

\section{$R T-P C R$}

After 3-hour incubation with stimulants, total RNA was isolated with the acid guanidiniumphenol-chloroform method using an Isogen kit (Nippon Gene, Tokyo, Japan). The concentration of RNA was determined by absorbance at $260 \mathrm{~nm}$ in relation to absorbance at $280 \mathrm{~nm}$. RNA was stored at $-70^{\circ} \mathrm{C}$ until RT was performed. One microliter of reverse transcription product was added to $3 \mathrm{mM}$ concentration of primers for ICAM-1, VCAM1, GAPDH (as an internal standard), in a solution containing $0.5 \mathrm{U}$ of Taq DNA polymerase (Takara Biochemicals, Shiga, Japan) in a final volume of $50 \mu \mathrm{l}$. Primers were as follows: for ICAM-1, sense 5' - AACCGGA AGGTGTATGAACTG -3', and antisense 5'CGAGGTGT TCTCAAACAGCTC -3'; for VCAM-1 sense 5' - CCAGAATCTA GATATCTTGCTC -3' and antisense 5'CAGCCTGT CAAATGGGTATAC -3'; and for GAPDH, sense 5' GGGGAGCCAAAAGGGTCATCATCT -3', and antisense 5'GAGGGGCCATCCACAGTCTTCT -3'. The mixture was subjected to PCR amplification for 25 cycles $\left(30 \mathrm{sec}\right.$ at $94^{\circ} \mathrm{C}, 30 \mathrm{sec}$ at $55^{\circ} \mathrm{C}$, and $1 \mathrm{~min}$ at $72^{\circ} \mathrm{C}$ ). Reaction products were separated electrophoretically on a $2.5 \%$ agarose gel and stained with ethidium bromide.

\section{Monocyte adhesion assay}

HAEC confluent monolayers prepared in 48well plates were stimulated with TNF- $\alpha$ (20 $\mathrm{ng} / \mathrm{ml}), 7 \beta$-hydroxycholesterol $(10 \mu \mathrm{M})$, or 25-hydroxycholesterol $(10 \mu \mathrm{M})$ for $4 \mathrm{~h}$ in the presence or absence of RWE. Subsequently, HAEC were washed with HBSS, and monocytes (U937 cells) were added to each well and incubated at $37^{\circ} \mathrm{C}$ for $30 \mathrm{~min}$. The plates were washed 3 times with HBSS and fixed in $1 \%$ paraformaldehyde in PBS. The number of adherent cells was counted in twenty microscopic fields defined by an eyepiece and each experiment was performed in triplicate.

\section{Statistical analysis}

Results were presented as the mean \pm SE. Data were analyzed using two-way analysis of variance (ANOVA) followed by Scheffe's test and $\mathrm{p}<0.05$ was taken to indicate statistical significance.

\section{RESULTS}

\section{Effect of $R W E$ on the expression of adhesion molecules}

The incubation of HAECs with RWE for 24 hours resulted in more than $96 \%$ viable cells, which indicates that RWE at concentrations from 1 to $100 \mathrm{ng} / \mathrm{ml}$ does not decrease cell viability. Figure 1 shows time course of surface expression of ICAM-1 and VCAM-1 on HAEC exposed to 7 $\beta$-hydroxycholesterol or 25-hydroxycholesterol. Expression of both ICAM-1 and VCAM-1 increased $6 \mathrm{~h}$ to $18 \mathrm{~h}$ after stimulation of these oxysterols. Figures 2 and 3 show the effects of RWE on surface expression of ICAM-1 and VCAM-1 on HAEC induced by pro-inflammatory cytokines or oxysterols. These stimulants significantly enhanced the surface expression of CAMs on HAEC 6 hours after stimulation. Pretreatment of HAEC with RWE at final concentrations of 1,10 , and $100 \mathrm{ng} / \mathrm{ml}$ for 10 hours significantly inhibited these enhancements of surface expression. The increased expression of CAMs by TNF- $\alpha$ or IL- $1 \beta$ was inhibited by about $30-50 \%$ by the pretreatment of RWE at a concentration of $100 \mathrm{ng} / \mathrm{ml}$; in contrast, the increase produced by oxysterols was completely reversed to the level prior stimulation by the pretreatment with RWE at a concentration of $10 \mathrm{ng} / \mathrm{ml}$. To 

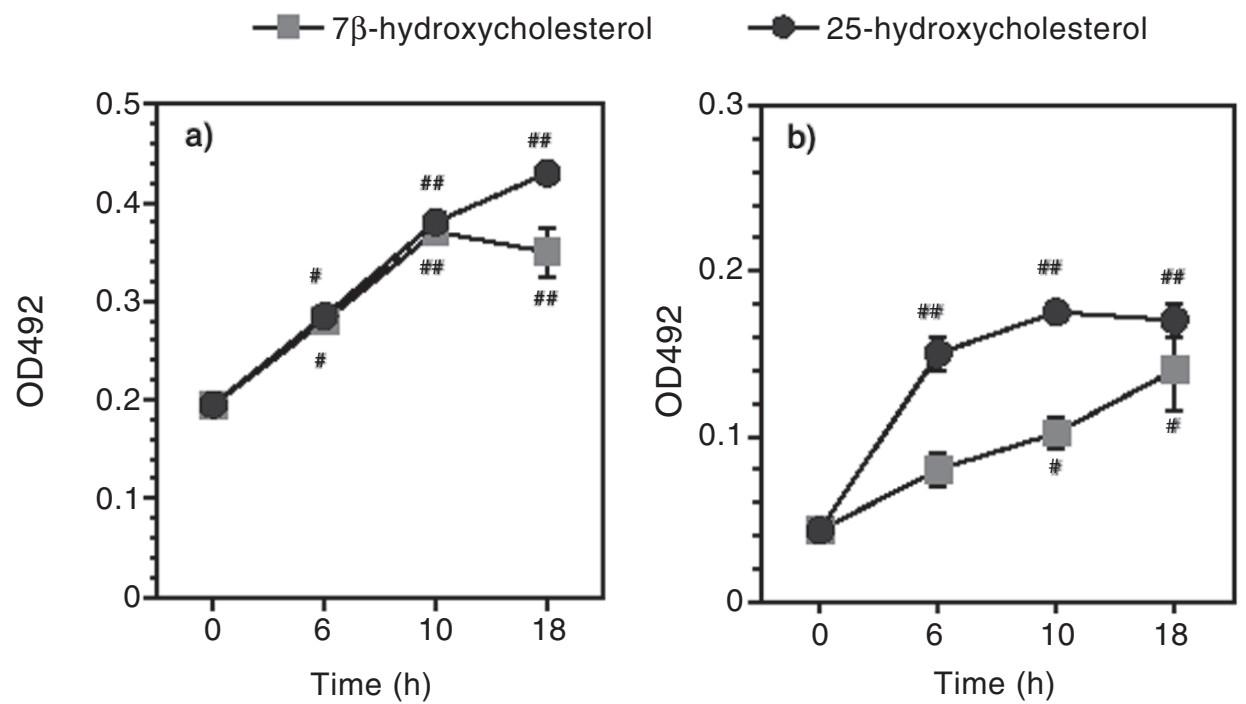

Figure 1. Time course of surface expression of intercellular adhesion molecule-1 (ICAM-1, Fig 1a) and vascular cell adhesion molecule-1 (VCAM-1, Fig 1b) on human aortic endothelial cells (HAEC) exposed to 7 $\beta$-hydroxycholesterol and 25-hydroxycholesterol.

Data are expressed as mean \pm SE of three experiments performed in duplicate. ${ }^{\#} \mathrm{p}<0.05$ and ${ }^{\# \#} \mathrm{p}<0.01$ vs. before stimulation.
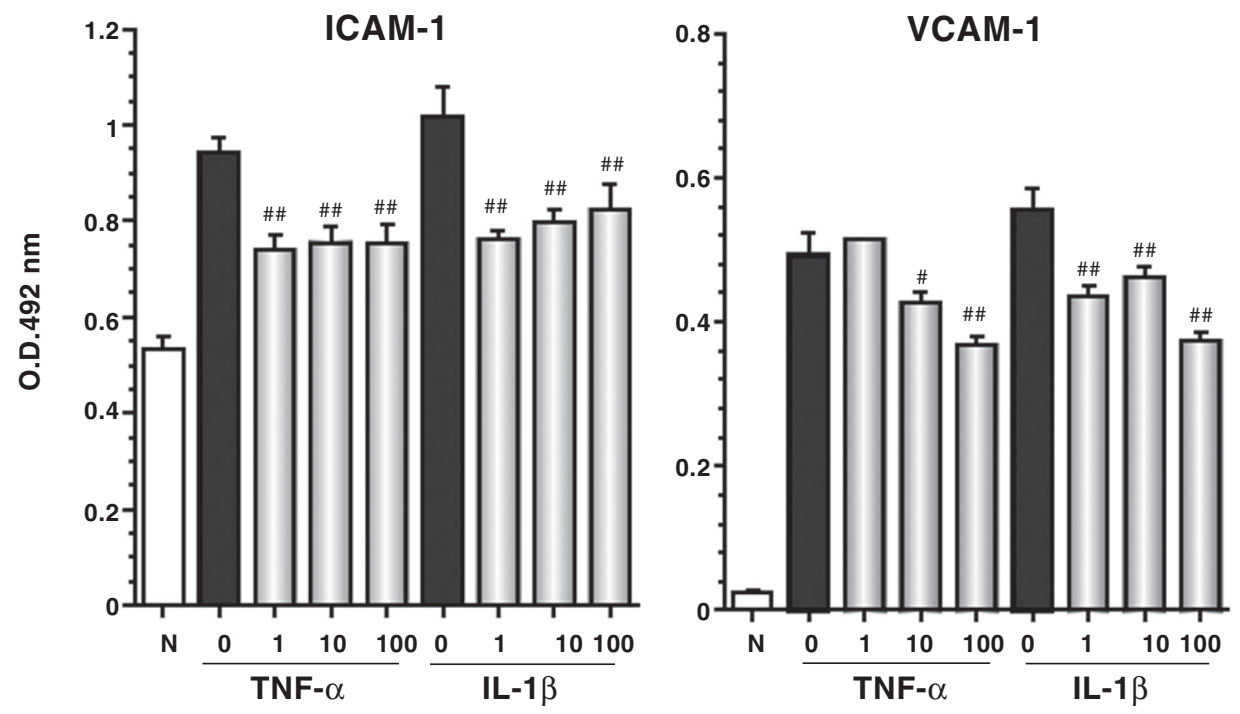

Wine extract $(\mathrm{ng} / \mathrm{ml})$

Figure 2. Effects of red wine extract (RWE) on intercellular adhesion molecule-1 (ICAM-1) and vascular cell adhesion molecule-1 (VCAM-1) on human aortic endothelial cells (HAEC) exposed to tumor necrosis factor- $\alpha$ (TNF- $\alpha$ ) or interleukin $1 \beta$ (IL-1 $\beta$ ).

Confluent HAEC were incubated with TNF- $\alpha(20 \mathrm{ng} / \mathrm{ml})$ or IL-1 $\beta(28 \mathrm{U} / \mathrm{ml})$ in the absence or presence of RWE at $37^{\circ} \mathrm{C}$ for $6 \mathrm{~h}$. The expression of ICAM-1 and VCAM-1 on the cell surface was measured using EIA. ${ }^{*} \mathrm{p}<0.05$ vs. unstimulated group, and $\# \mathrm{p}<0.05$ and $\# \# \mathrm{p}<0.01$ vs. stimulated group without RWE. 

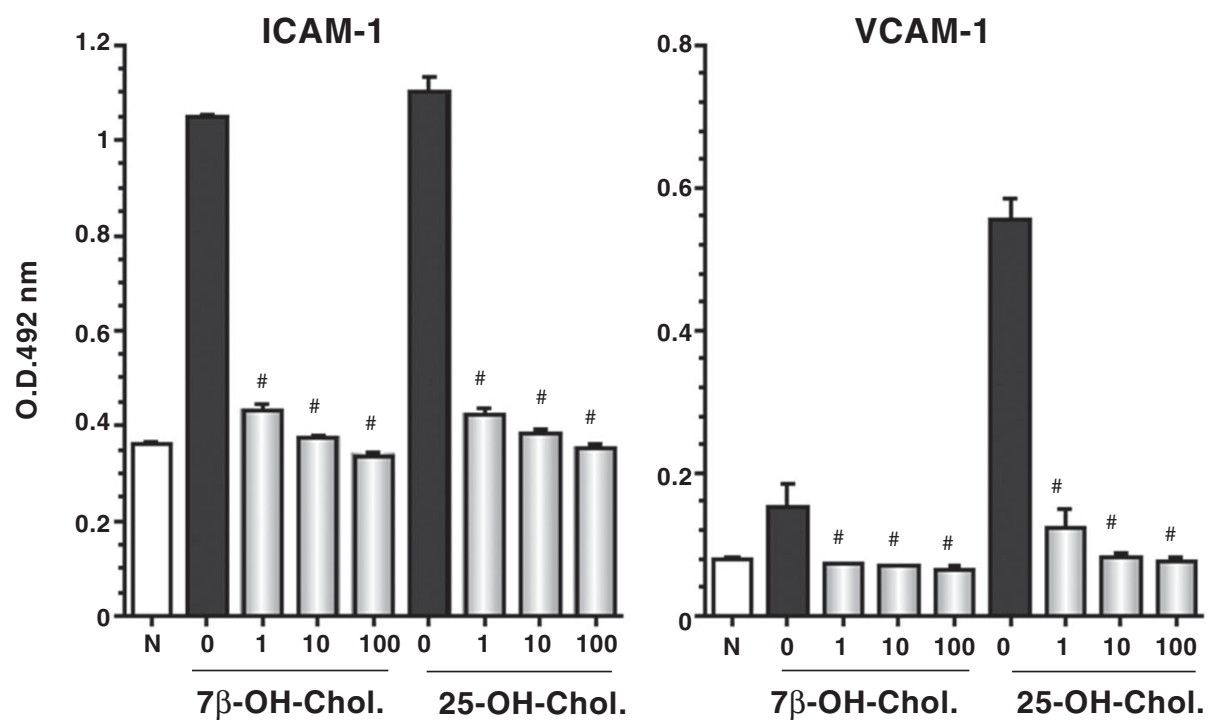

Wine extract $(\mathrm{ng} / \mathrm{ml})$

Figure 3. Effects of red wine extract (RWE) on intercellular adhesion molecule-1 (ICAM-1) and vascular cell adhesion molecule-1 (VCAM-1) on human aortic endothelial cells (HAEC) exposed to $7 \beta$-hydroxycholesterol ( $7 \beta-\mathrm{OH}-\mathrm{Chol})$ or 25 -hydroxycholesterol $(25-\mathrm{OH}-\mathrm{Chol})$.

Confluent HAEC were incubated with $7 \beta-\mathrm{OH}-\mathrm{Chol}(10 \mu \mathrm{M})$ or $25-\mathrm{OH}-\mathrm{Chol}(10 \mu \mathrm{M})$ in the absence or presence of RWE at $37^{\circ} \mathrm{C}$ for $6 \mathrm{~h}$. The expression of ICAM-1 and VCAM-1 on the cell surface was measured using EIA. ${ }^{*} \mathrm{p}<0.05$ vs. unstimulated group, and $\# \mathrm{p}<0.01$ vs. stimulated group without RWE.

further analyze effects of RWE on the expression of adhesion molecules, we assessed mRNA expression for ICAM-1 and VCAM-1 using RT-PCR yielding 390-, 354, and 235-base pair products to identify ICAM-1, VCAM-1, and GAPDH gene expression, respectively. As shown in Figure 4, we found ICAM-1 and VCAM-1 gene expression in HAEC before stimulation to be negligible or faint. In contrast, the expression of ICAM-1 and VCAM-1 genes was up-regulated after stimulation. These increases in mRNA expression were inhibited by the treatment with RWE at a concentration of $10 \mu \mathrm{M}$.

Effect of RWE on monocyte adhesion to endothelial cells

The adherence of monocytes to HAEC exposed to TNF- $\alpha, 7 \beta$-hydroxycholesterol, and 25-hydroxycholesterol significantly increased compared to that of unstimulated
HAEC. Figure 5 shows the effect of RWE on the adherence of monocytes to TNF- $\alpha$, $7 \beta$-hydroxycholesterol-, or 25hydroxycholesterol-stimulated HAEC. Pretreatment of HAEC with RWE significantly reduced the adherence of monocytes on HAEC.

\section{DISCUSSION}

Clinical studies and animal experiments have demonstrated that oxLDL and oxysterols play important roles in atherogenesis. Yasunobu et al. (11) have demonstrated that serum concentration of oxysterols is significantly increased in patients with coronary heart disease. Oxysterols have also been found in atherosclerotic lesions in both human and animal models $(12,13)$. Oxysterols are biologically active molecules that promote atherosclerosis: 7 $\beta$-hydroxycholesterol and 
7-ketocholesterol induce nuclear condensation and/or fragmentation, internucleosomal DNA fragmentation, and IL-1 $\beta$ secretion (14); 25-hydroxylcholesterol induces apoptosis in monocyte-macrophages (15); oxysterols may have a regulatory effect on IL-8 production from macrophages in oxLDL (16); and 7 $\beta$-hydroxycholesterol and 7-ketocholesterol have dual cytotoxic effects on the cells of the vascular wall by their ability to induce apoptosis in endothelial and smooth muscle cells and necrosis in fibroblasts (17). We recently found that 7ketocholesterol and 7 $\beta$-hydroxycholesterol induced apoptosis in human umbilical vein endothelial cells and this cytotoxicity was reduced by treatment with $\alpha$-tocopherol (18). The present study confirmed the increased expression of ICAM-1 and
VCAM-1 on the surface of aortic endothelial cells stimulated with 7 $\beta$-hydroxycholesterol and 25-hydroxycholesterol, and also showed that RWE significantly inhibited these increases. To assess the mechanism of the inhibitory effect of RWE, we investigated the expression of mRNA of ICAM-1 and VCAM-1 genes after stimulation by oxysterols using RT-PCR. The expression of these genes was also significantly inhibited by the treatment with RWE, supporting the hypothesis that RWE attenuates oxysterolinduced expression of adhesion molecules by inhibiting the up-regulation of mRNA of these genes. However, the intracellular pathway by which RWE causes inhibition of ICAM-1/VCAM-1 expression is not fully understood. The precise mechanism is now under investigation.

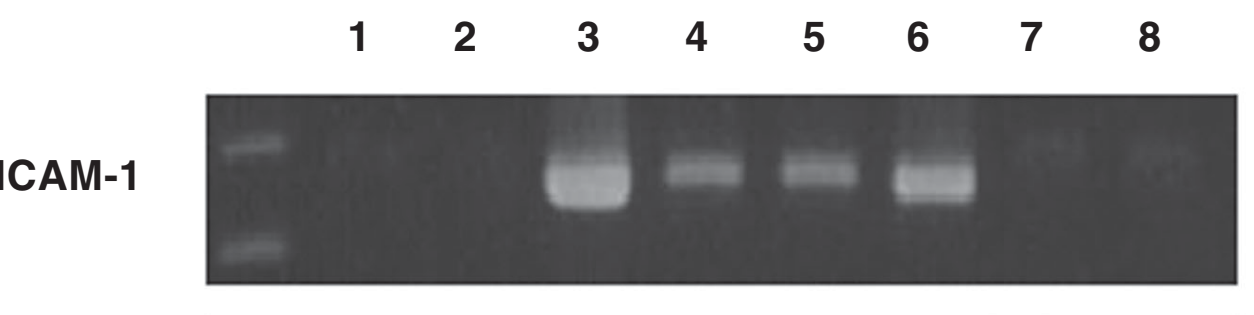

VCAM-1

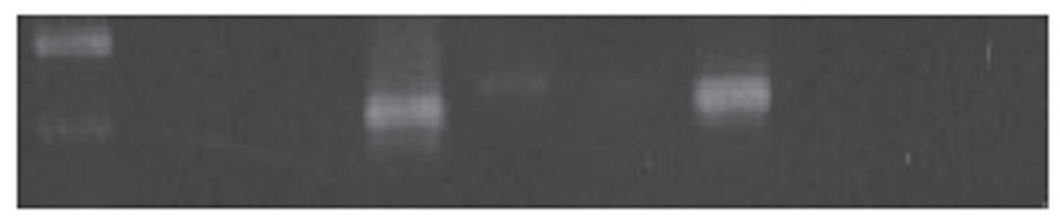

G3PDH

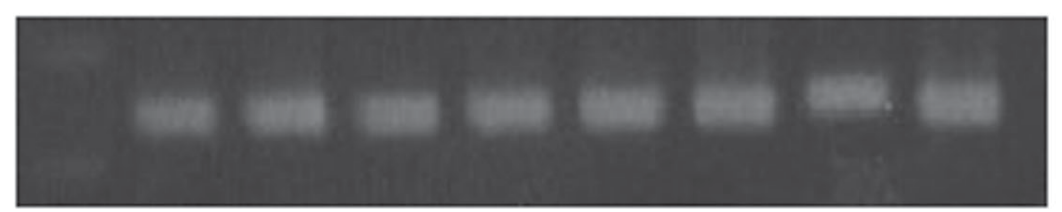

Figure 4. Effects of red wine extract (RWE) on mRNA expression for intercellular adhesion molecule-1 (ICAM-1) and vascular cell adhesion molecule-1 (VCAM-1) exposed to tumor necrosis factor- $\alpha$ (TNF- $\alpha$ ), 7 $\beta$-hydroxycholesterol (7 $\beta-\mathrm{OH}-\mathrm{Chol}$ ), or 25-hydroxycholesterol (25-OH-Chol). Confluent HAEC were incubated with each stimulant in the absence or presence of RWE at $37^{\circ} \mathrm{C}$ for $3 \mathrm{~h}$.

A representative $2 \%$ agarose gel of RT-PCR products is shown, including mRNA for unstimulated cells treated with vehicle (lane 1) and RWE (lane 2), TNF- $\alpha$-stimulated cells treated with vehicle (lane 3) and RWE (lane 6), 7 $\beta$-hydroxycholesterol-stimulated cells treated with vehicle (lane 4) and RWE (lane 7), and 25-hydroxycholesterol-stimulated cells treated with vehicle (lane 5) and RWE (lane 8). 

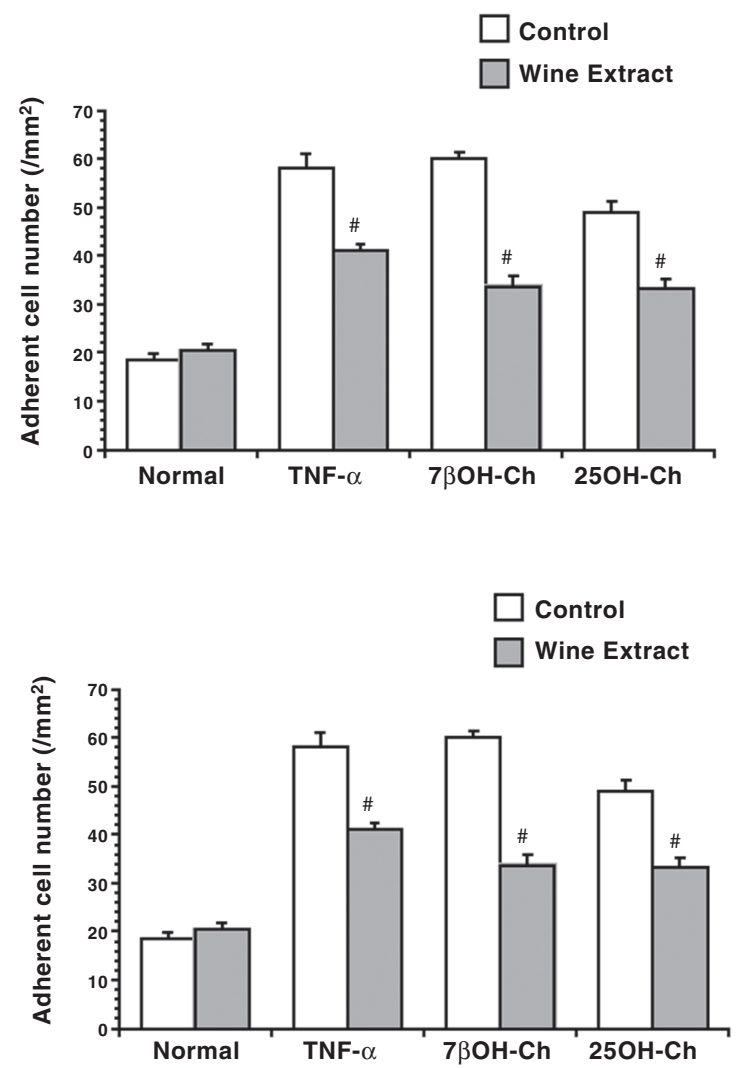

Figure 5. Effects of red wine extract (RWE) on monocyte adhesion on HAEC exposed to tumor necrosis factor- $\alpha$ (TNF- $\alpha), \quad 7 \beta$ hydroxycholesterol (7ß-OH-Chol), or 25 hydroxycholesterol (25-OH-Chol).

HAEC stimulated with TNF- $\alpha(20 \mathrm{ng} / \mathrm{ml}), 7 \beta-$ OH-Chol $(10 \mu \mathrm{M})$, or $25-\mathrm{OH}-\mathrm{Chol}(10 \mu \mathrm{M})$ for $4 \mathrm{~h}$ was incubated with non-stimulated monocytes (U937) for $30 \mathrm{~min}$. $* \mathrm{p}<0.01 \mathrm{vs}$. unstimulated group, and $\# \mathrm{p}<0.01$ vs. stimulated group without RWE.

Our previous study demonstrated that the adhesion of monocytes to endothelial cells exposed to oxLDL involved CD18/ ICAM-1 dependent pathway or both CD18/ ICAM-1 and VLA-4/VCAM-1 dependent interactions, respectively (19). Monoclonal antibodies against ICAM-1, VCAM-1, CD18, or very late antigen (VLA)-4 significantly reduced monocyte adherence to oxLDL-stimulated HUVEC, indicating that the interaction between monocyte and oxLDL-stimulated endothelial cells involves both CD18/ICAM-1- and VLA-4/ VCAM-1-dependent pathways. Kammana et al. (20) have shown the activation of glomerular endothelial cells with oxLDL, prepared by incubating LDL with $\mathrm{CuSO}_{4}$, stimulated ICAM-1 mRNA transcripts and protein synthesis and enhanced the adhesion of monocytes to endothelial cells. In the present study, RWE reduced monocyte adhesion to the same levels as inhibition of ICAM-1 and VCAM-1 expression. These results suggest that reduction of monocyte adhesion by RWE may be attributed to decreased adhesion molecule expression. Of high interest is the identification of the constituents that may be responsible for the observed RWE effect. Red wine extract contains polyphenolic compounds such as catechins, quercetin, resveratrol, anthocyanins, flavanols, and flavonols. Of these, resveratrol (21), anthocyanins (22), and gallates (8) have been suggested to inhibit the up-regulation of adhesion molecule expression on endothelial cells stimulated with TNF- $\alpha$ and lipopolysaccharide. The resveratrol and anthocyanin content in the RWE we used was moderately high, as shown in Table I. However, no data from HAEC stimulated with oxysterol have been presented. Further investigation is needed to determine the bioavailability and pharmacokinetics of polyphenols and to identify ingredients of red wine components that may mediate red wine antiinflammatory activity.

Recent studies show that dietary consumption of red wine $(0.5 \mathrm{~mL} /$ day per mouse) by apolipoprotein-deficient mice significantly attenuates the development of atherosclerotic lesions (23). This antiatherosclerotic effect is, in part, associated with the inhibition of monocyte-endothelial interaction induced by oxLDL. In conclusion, oxysterol induces the monocyte-endothelial interaction in vitro via increased expression of adhesion molecules on HAEC. The inhibitory effects of RWE on expression of adhesion molecules and monocyte adhesion to endothelial cells may protect blood vessels from atherosclerotic processes associated with oxysterol-induced injury. 


\section{ACKNOWLEDGMENTS}

This work was supported by Grant-in-Aid for Scientific Research (14570493 YN) from the Ministry of Education, Culture, Sports, Science and Technology of Japan, and by Grant from Bio-oriented Technology Research Advancement Institution.

\section{REFERENCES}

1. STEINBERG D (1997) Low density lipoprotein oxidation and its pathobiological significance. J Biol Chem 272: 20963-20966

2. COLLINS RG, VELJI R, GUEVARA NV, HICKS MJ, CHAN L, BEAUDET AL (2000) P-Selectin or intercellular adhesion molecule (ICAM)-1 deficiency substantially protects against atherosclerosis in apolipoprotein E-deficient mice. J Exp Med 191: 189194

3. MURAYAMA T, YOKODE M, KATAOKA H, IMABAYASHI T, YOSHIDA H, SANO H, NISHIKAWA S, KITA T (1999) Intraperitoneal administration of anti-c-fms monoclonal antibody prevents initial events of atherogenesis but does not reduce the size of advanced lesions in apolipoprotein E-deficient mice. Circulation 99: 1740-17464

4. RENAUD S, DE LORGERIL M (1992) Wine, alcohol, platelets, and the French paradox for coronary heart disease. Lancet 339: 1523-1526

5. WU JM, WANG ZR, HSIEH TC, BRUDER JL, ZOU JG, HUANG YZ (2001) Mechanism of cardioprotection by resveratrol, a phenolic antioxidant present in red wine (Review). Int J Mol Med 8: 3-17

6. FRANKEL EN, KANNER J, GERMAN JB, PARKS E, KINSELLA JE (1993) Inhibition of oxidation of human low-density lipoprotein by phenolic substances in red wine. Lancet 341: 454-457

7. KONDO K, MATSUMOTO A, KURATA H, TANAHASHI H, KODA H, AMACHI T, ITAKURA H (1994) Inhibition of oxidation of low-density lipoprotein with red wine. Lancet 344: 1152

8. MURASE T, KUME N, HASE T, SHIBUYA Y, NISHIZAWA Y, TOKIMITSU I, KITA T (1999) Gallates inhibit cytokine-induced nuclear translocation of NF-kappaB and expression of leukocyte adhesion molecules in vascular endothelial cells. Arterioscler Thromb Vasc Biol 19: 1412-1420

9. DEMROW HS, SLANE PR, FOLTS JD (1995) Administration of wine and grape juice inhibits in vivo platelet activity and thrombosis in stenosed canine coronary arteries. Circulation 91: 1182-11886

10. ANDRIAMBELOSON E, STOCLET JC, ANDRIANTSITOHAINA R (1999) Mechanism of endothelial nitric oxide-dependent vasorelaxation induced by wine polyphenols in rat thoracic aorta. J Cardiovasc Pharmacol 33: 248-254

11. YASUNOBU Y, HAYASHI K, SHINGU T, YAMAGATA T, KAJIYAMA G, KAMBE M (2001) Coronary atherosclerosis and oxidative stress as reflected by autoantibodies against oxidized lowdensity lipoprotein and oxysterols. Atherosclerosis 155: 445-453
12. BREUER O, DZELETOVIC S, LUND E, DICZFALUSY U (1996) The oxysterols cholest-5-ene3 beta, 4 alpha-diol, cholest-5-ene- 3 beta, 4 beta-diol and cholestane- 3 beta, 5 alpha, 6 alpha-triol are formed during in vitro oxidation of low density lipoprotein, and are present in human atherosclerotic plaques. Biochim Biophys Acta 1302: 145-152

13. VAYA J, AVIRAM M, MAHMOOD S, HAYEK T, GRENADIR E, HOFFMAN A, MILO S (2001) Selective distribution of oxysterols in atherosclerotic lesions and human plasma lipoproteins. Free Radic Res 34: 485-497

14. LIZARD G, LEMAIRE S, MONIER S, GUELDRY S, NEEL D, GAMBERT P (1997) Induction of apoptosis and of interleukin-1beta secretion by 7beta-hydroxycholesterol and 7-ketocholesterol: partial inhibition by $\mathrm{Bcl}-2$ overexpression. FEBS Lett 419: 276-280.

15. HARADA K, ISHIBASHI S, MIYASHITA T, OSUGA J-I, YAGYU H, OHASHI K, YAZAKI Y, YAMADA N (1997) Bcl-2 protein inhibits oxysterol-induced apoptosis through suppressing CPP32-mediated pathway. FEBS Lett 411: 63-66

16. LIU Y, HULTEN LM, WIKLUND O (1997) Macrophages isolated from human atherosclerotic plaques produce IL- 8 , and oxysterols may have a regulatory function for IL-8 production. Arterioscler Thromb Vasc Biol 17: 317-323.

17. LIZARD G, MONIER S, CORDELET C, GESQUIERE L, DECKERT V, GUELDRY S, LAGROST L, GAMBERT P (1999) Characterization and comparison of the mode of cell death, apoptosis versus necrosis, induced by 7beta-hydroxycholesterol and 7 ketocholesterol in the cells of the vascular wall. Arterioscler Thromb Vasc Biol 19: 1190-1200.

18. UEMURA M, MANABE H, YOSHIDA N, FUJITA N, OCHIAI J, MATSUMOTO N, TAKAGI T, NAITO Y, YOSHIKAWA T (2002) alpha-Tocopherol prevents apoptosis of vascular endothelial cells via a mechanism exceeding that of mere antioxidation. Eur J Pharmacol 456: 29-37

19. YOSHIDA N, MANABE H, TERASAWA Y, NISHIMURA H, ENJO F, NISHINO H, YOSHIKAWA $\mathrm{T}$ (2000) Inhibitory effects of vitamin $\mathrm{E}$ on endothelialdependent adhesive interactions with leukocytes induced by oxidized low density lipoprotein. Biofactors 13: $279-288$

20. KAMANNA VS, PAI R, HA H, KIRSCHENBAUM MA, ROH DD (1999) Oxidized low-density lipoprotein stimulates monocyte adhesion to glomerular endothelial cells. Kidney Int 55: 2192-2202.

21. FERRERO ME, BERTELLI AE, FULGENZI A, PELLEGATTA F, CORSI MM, BONFRATE M, FERRARA F, DE CATERINA R, GIOVANNINI L, BERTELLI A (1998) Activity in vitro of resveratrol on granulocyte and monocyte adhesion to endothelium. Am J Clin Nutr 68: 1208-1214

22. SEN CK, BAGCHI D (2001) Regulation of inducible adhesion molecule expression in human endothelial cells by grape seed proanthocyanidin extract. Mol Cell Biochem 216: 1-7

23. HAYEK T, FUHRMAN B, VAYA J, ROSENBLAT M, BELINKY P, COLEMAN R, ELIS A, AVIRAM M (1997) Reduced progression of atherosclerosis in apolipoprotein E-deficient mice following consumption of red wine, or its polyphenols quercetin or catechin, is associated with reduced susceptibility of LDL to oxidation and aggregation. Arterioscler Thromb Vasc Biol 17: 2744-2752 